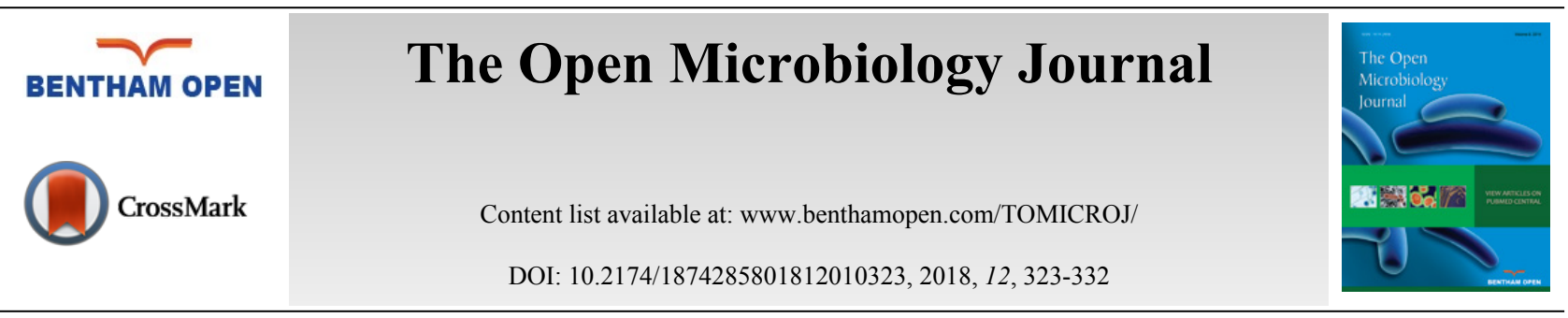

RESEARCH ARTICLE

\title{
First Molecular Identification of Symbiotic Archaea in a Sponge Collected from the Persian Gulf, Iran
}

\author{
Akram Najafi $^{1}$, Maryam Moradinasab ${ }^{2}$, Mohammad Seyedabadi ${ }^{3}$, Mohammad A. Haghighi $^{4}$ and Iraj \\ Nabipour ${ }^{1, *}$ \\ ${ }^{I}$ The Persian Gulf Marine Biotechnology Research Center, Bushehr University of Medical Sciences, Bushehr, Iran \\ ${ }^{2}$ The Persian Gulf Tropical Medicine Research Center, Bushehr University of Medical Sciences, Bushehr, Iran \\ ${ }^{3}$ Department of Pharmacology, School of Medicine, Bushehr University of Medical Sciences, Bushehr, Iran \\ ${ }^{4}$ Department of Microbiology and Parasitology, Faculty of Medicine, Bushehr University of Medical Sciences, Bushehr, \\ Iran
}

Received: July 17, 2018

Revised: September 21, 2018

Accepted: September 23, 2018

\section{Abstract:}

\section{Background:}

Marine sponges are associated with numerically vast and phylogenetically diverse microbial communities at different geographical locations. However, little is known about the archaeal diversity of sponges in the Persian Gulf. The present study was aimed to identify the symbiotic archaea with a sponge species gathered from the Persian Gulf, Iran.

\section{Methods:}

Sponge sample was collected from a depth of $3 \mathrm{~m}$ offshore Bushehr, Persian Gulf, Iran. Metagenomic DNA was extracted using a hexadecyl trimethyl ammonium bromide (CTAB) method. The COI mtDNA marker was used for molecular taxonomy identification of sponge sample. Also, symbiotic archaea were identified using the culture-independent analysis of the $16 S$ rRNA gene and PCRcloning.

\section{Results:}

In this study, analysis of multilocus DNA marker and morphological characteristics revealed that the sponge species belonged to Chondrilla australiensis isolate PG_BU4. PCR cloning and sequencing showed that all of the sequences of archaeal $16 S$ rRNA gene libraries clustered into the uncultured archaeal group.

\section{Conclusion:}

The present study is the first report of the presence of the genus of Chondrilla in the Persian Gulf. Traditional taxonomy methods, when used along with molecular techniques, could play a significant role in the accurate taxonomy of sponges. Also, the uncultured archaea may promise a potential source for bioactive compounds. Further functional studies are needed to explore the role of the sponge-associated uncultured archaea as a part of the marine symbiosis.

Keywords: Porifera, Uncultured Archaea, Symbiosis, Chondrilla australiensis, Persian Gulf, Taxonomy.

\section{INTRODUCTION}

Marine sponges are one of the oldest and most important multicellular animals (metazoans) and reef builders in benthic communities' worldwide [1,2]. In the past decade, many studies have focused on the sponge-associated

\footnotetext{
* Address correspondence to this author at the The Persian Gulf Marine Biotechnology Research Center, Bushehr University of Medical Sciences, Bushehr, Iran; Tel: +98 7733350406; Fax: +98 7733350406; E-mail: nabipour@bpums.ac.ir
} 
microbial communities because of their benefit the hosts with different functional roles [3 - 6]. These microorganisms constitute up to $40-60 \%$ of the total sponge biomass and may affect the sponge survival in the marine through producing bioactive secondary metabolites, photosynthesis, nitrogen and sulfur fixation, etc. $[1,4,5,7]$.

Traditionally, the taxonomy of marine sponges is defined based on morphological features, using some diagnostic characters. Because of the limitations of informative characters and a wide range of phenotypic plasticity, the sponge classifications have been hindered [8]. Currently, molecular data have been particularly used in sponge phylogenetic analysis, with the variable $28 \mathrm{~S}$ rDNA region, the highly variable Internal Transcribed Spacer (ITS) region, and mitochondrial DNA (cytochrome oxidase subunit 1 (COI)) [9].

Archaea are comprised the third phylogenetic domain of life and their presence in sponge larvae reveals a tight relationship between archaeal symbionts and the sponge host phylogeny $[10,11]$. However, environmental factors including seasonal changes in seawaters or geographical distribution of sponges may also influence the relationship [12].

Within the past two decades, culture-independent techniques such as $16 S r R N A$ gene-based clone library have led to a deeper understanding of the microbial diversity, and a wide distribution of mostly uncultured archaea in different species sponges [13 - 15]. More than 20,000 archaeal $16 S$ rRNA gene sequences have been presented from environmental studies, extending the known groups and introducing of novel lineages [13].

To date, more than 25 different bacterial phyla and 2 archaeal lineages have been reported from sponge species from different geographic locations $[2,11,16]$. But little is known from the Persian Gulf. The Persian Gulf, is a unique and greatly underexplored marine ecosystem containing 55 sponge genera recorded [17]. To our knowledge there is no research reported on the archaeal communities of sponges in Iran.

The present study was aimed to identify the symbiotic archaea with a sponge species (Chondrilla australiensis isolate PG_BU4) collected from the Persian Gulf, Iran.

\section{MATERIALS AND METHODS}

\subsection{Sampling and Identification of Sponge}

Sponge sampling was performed in July 2016 at a depth of $3 \mathrm{~m}$ offshore Bushehr, Persian Gulf, Iran (GPS: $28^{\circ} 58^{\prime} 54.4^{\prime \prime} \mathrm{N} 50^{\circ} 49^{\prime} 27.8^{\prime \prime E}$ ) by SCUBA diving. Sponge sample was raised with $0.22-\mu \mathrm{m}-\mathrm{membrane}$-filtered seawater (FSW) to remove exogenous materials and loosely attached microbes. Sample was placed in sterile plastic Ziploc bags and immediately transported to the laboratory on dry ice and then frozen at $-80^{\circ} \mathrm{C}[18]$.

\subsection{Morphological Identification of Sponge}

In this study, morphological and spicule examination was carried out by Dr. Yusheng M. Huang (National Penghu University of Science and Technology, Taiwan). The skeleton and spicule slide were examined using a compound light microscope (Leica DM2500 with MC170 HD Camera \& SW Kit) and photographed and measured using Leica Application Suite ver. 4.11. The morphological features of sponge spicules, skeletons, and choanocyte chambers were described using Boury-Esnault and Rützler 1997 and further identified according to the key, Systema Porifera: A guide to the Classification of Sponges [8] and references provided by the World Porifera Database [19].

\subsection{Metagenomic DNA Extraction}

Sponge sample was washed with sterilized seawater and cut into small pieces (about $1 \mathrm{~cm}^{3}$ ). Sponge tissues were ground to fine powder under liquid $\mathrm{N}_{2}$ using a sterile pestle and mortar $[10,18]$. Metagenomic DNA was extracted using a hexadecyltrimethylammonium bromide (CTAB) according to Schmitt et al. 2012 method [20]. Metagenomic DNA was qualified by electrophoresis on $1 \%$ agarose gel. The quantitative assessment of the isolated DNA was carried out using a NanoDrop ND-100 device (Thermo Fisher, USA) and then stored at $-20{ }^{\circ} \mathrm{C}$ until use.

\subsection{Sponge COI gene PCR}

In this study, a mitochondrial gene, cytochrome oxidase subunit 1 (COI) was amplified. Primer sequences are shown in Table 1. Briefly, a single reaction mixture containing $2.5 \mu 1$ of 10x buffer (supplied with Taq polymerase), 1 $\mu \mathrm{l}$ of DNA (approximately $100 \mathrm{ng} / \mu \mathrm{l}), 0.5 \mu \mathrm{l}$ of each appropriate primer $(10 \mathrm{mM})$ (Shanghai Generay Biotech Co., Ltd), $3 \mu \mathrm{l}$ dNTPs $(1 \mathrm{mM}), 1 \mu \mathrm{l}$ of $\mathrm{MgCl}_{2}, 0.25 \mu \mathrm{l}$ of Taq DNA polymerase (Fermentase, Lithuania) in a total volume of 
$25 \mu \mathrm{l}$ [21]. PCR amplifications were carried out on a thermal cycler PeQlab, peqSTAR 96X Universal Gradient, Germany under the following conditions: $94^{\circ} \mathrm{C}$ for $5 \mathrm{~min}$; followed by 35 cycles of $94^{\circ} \mathrm{C}$ for $40 \mathrm{~s} ; 58^{\circ} \mathrm{C}$ for $30 \mathrm{~s} ; 72^{\circ} \mathrm{C}$ for $40 \mathrm{~s}$; followed by $72^{\circ} \mathrm{C}$ for $5 \mathrm{~min}$. PCR products were purified and sequenced by Macrogen Inc (Seoul, Korea).

Table 1. Primer sequences used for identification of sponge and Archaea.

\begin{tabular}{|c|c|c|c|c|}
\hline Organism & Primers & Sequences & Size (bp) & Reference \\
\hline \multirow{2}{*}{ Sponge } & LCO1490 F & 5'- GGTCAACAAATCATAAAGATATTGG- 3' & \multirow{2}{*}{500} & \multirow{2}{*}[22]{} \\
\hline & $\mathrm{HCO} 2198 \mathrm{R}$ & 5'- TAAACTTCAGGGTGACCAAAAAATCA- 3' & & \\
\hline \multirow{2}{*}{ Archaea } & $21 \mathrm{~F}$ & 5'- TTCCGGTTGATCCYGCCGGA- 3' & \multirow{2}{*}{1300} & \multirow{2}{*}[23]{} \\
\hline & 1492R & 5'- GGTTACCTTGTTACGACTT- 3' & & \\
\hline
\end{tabular}

\subsection{Archaea 16S rRNA gene PCR}

Approximately 1000 to $1300 \mathrm{bp}$ of the $16 \mathrm{~S}$ rRNA gene was amplified by PCR using the universal archaeal primers (Table 1). PCR consisted of a reaction of $25 \mu \mathrm{l}$ with: $2.5 \mu \mathrm{l}$ of $10 \mathrm{x}$ buffer, $1 \mu \mathrm{l}$ of DNA (approximately $100 \mathrm{ng} / \mu \mathrm{l}$ ), $1 \mu \mathrm{l}$ of each forward and reverse primers $(10 \mathrm{mM})$ (Shanghai Generay Biotech Co., Ltd), $0.5 \mu 1$ of dNTPs (1 mM), $1 \mu 1$ of $\mathrm{MgCl}_{2}, 0.5 \mu \mathrm{l}$ of Taq DNA polymerase (Fermentase, Lithuania). Thermal cycling was initiated with denaturation at $94 \circ \mathrm{C}$ for $5 \mathrm{~min}$, followed by 30 cycles of $15 \mathrm{~s}$ at $94{ }^{\circ} \mathrm{C}, 30 \mathrm{~s}$ at 51 and $72 \circ \mathrm{C}$ for $1 \mathrm{~min}$ and a final extension step for 7 min at $72{ }^{\circ} \mathrm{C}$ [23]. PCR products were purified using the NucleoSpin ${ }^{\circledR}$ Gel and PCR Clean-up (Macherey-Nagel, Germany) and quantified using NanoDrop ND-100 device (Thermo Fisher, USA).

\subsection{Cloning of PCR Products and DNA Sequence Analysis}

16S rRNA gene libraries were constructed in JM109 Escherichia coli competent cell using a pGEM $\mathbb{R}-\mathrm{T}$ easy cloning kit (Promega, USA) following the manufacturers' instructions. After a blue-white screening, presumptive recombinant white colonies were randomly picked, subcultured onto LB agar containing ampicillin $100 \mathrm{mg} \mathrm{ml}^{-1}$, X-Gal $80 \mathrm{mg} \mathrm{ml}^{-1}$, and IPTG $0.5 \mathrm{mM}$. Individual clones were PCR-screened using universal primers and 10 clones with approximately 1000 to $1300 \mathrm{bp}$ inserts were recovered from samples. Plasmid DNA was purified using the NucleoSpin ${ }^{\circledR}$ Plasmid and NucleoBond ${ }^{\circledR}$ Xtra Midi kits (Macherey-Nagel, Germany), according to the manufacturer, from the selected colonies [24]. Inserts of representative plasmids were sent to Macrogen Inc (Seoul, Korea) for two reads sequencing using both vector primers (pUC/M13F: 5'-d(GTTTTCCCAGTCACGAC)-3' and pUC/M13R: 5'$\left.\mathrm{d}(\mathrm{CAGGAAACAGCTATGAC})-3^{\prime}\right)$ and primers used to generate the corresponding library.

\subsection{Phylogenetic Analysis}

All nucleotide sequences obtained for $16 \mathrm{~S} r R N A$ and COI genes phylogenetic analysis and their top BLASTN hits (GenBank database) were manually edited and aligned using the ClustalW (v. 1.81) program. Consequently, two alignment datasets were generated: 588 sites of 5 sequences (COI for sponges) and 1391 sites of 20 sequences (16S $r R N A$ for archaea). The alignment dataset was analyzed using Maximum Likelihood (ML) and Neighbor-Joining (NJ) methods. Maximum likelihood and neighbor-joining analyses were conducted using the MEGA7 (v. 7.0.18) program, with 1000 bootstrap resamplings.

\section{RESULTS}

\subsection{Sponge Identification}

In the present study, the collected sponge was identified as Chondrilla australiensis by Dr. Yusheng M. Huang (National Penghu University of Science and Technology, Taiwan), based on morphological characteristics. The sponge specimen was massive and sub-globose. The sponge had a combination of yellow-brown and greenish to dark brown colors, with shiny, smooth, and slippery surface and thickly encrusting (Fig. 1).

Ectosome had a layer of dense spherasters (Fig. 2A). The cortex was about 335-804 $\mu \mathrm{m}$ thick with a cuticle of about 74-149 $\mu \mathrm{m}$ (Fig. 2B). It was composed of two layers; the upper one had a dense sheet of sherulous cells and spherasters (Fig. 2C), whereas the internal one was made of scattered spherulous cells and spheraters. Also, Spheraster was 20-23-26 $\mu \mathrm{m}$ and Speroxyaster about $20 \mu \mathrm{m}$ (Fig. 2D). 


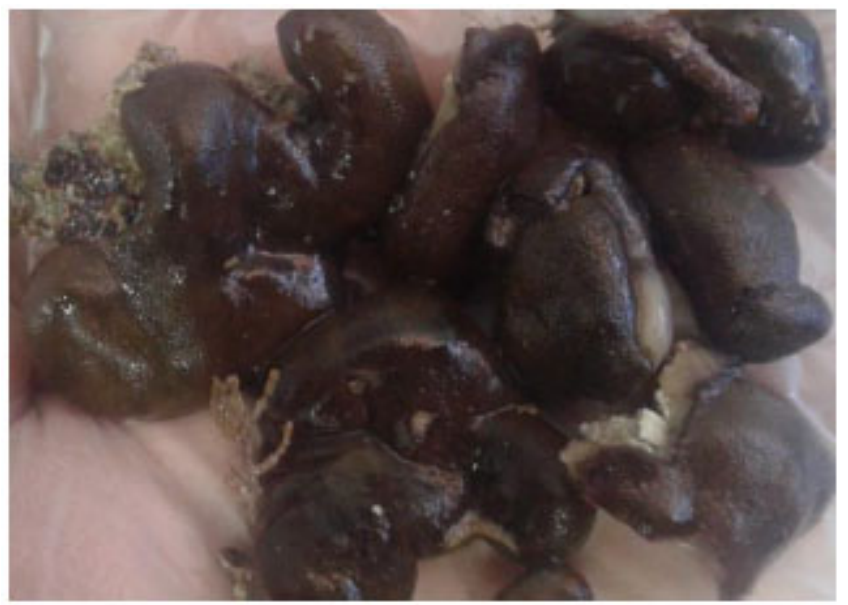

Fig. (1). A Chondrilla australiensis yellow-brown color morph.
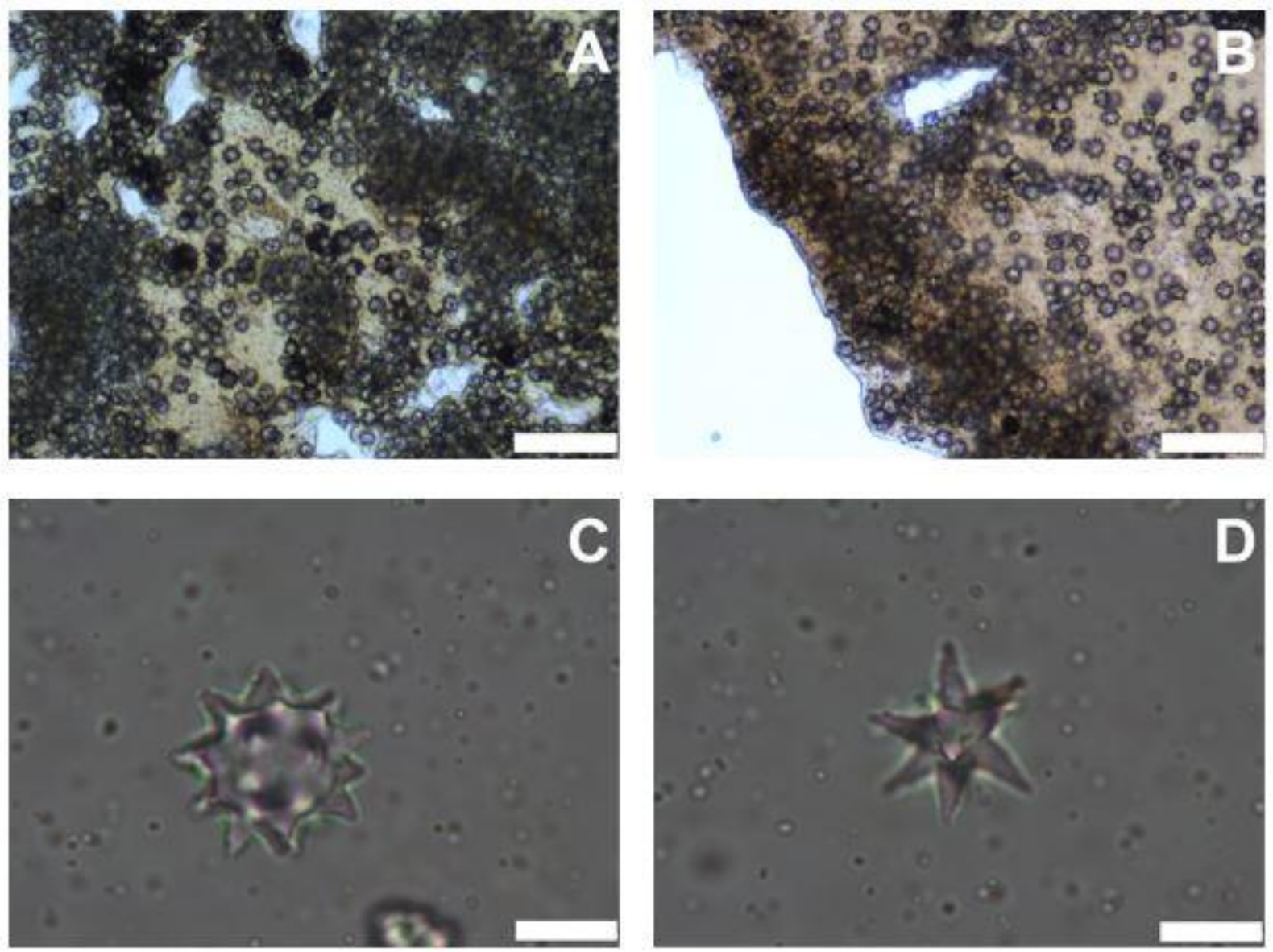

Fig. (2). Light micrograph of Chondrilla australiensis skeleton. A) Ectosomal skeleton (scale bar $100 \mu \mathrm{m})$, B) Choanosomal skeleton (scale bar $100 \mu \mathrm{m})$, C) Spheraster (scale bar $10 \mu \mathrm{m})$, D) Speroxyaster (scale bar $10 \mu \mathrm{m}$ ).

\subsection{Phylogeny of COI}

PCR of metagenomic DNA isolated from sponge Chondrilla australiensis tissue samples using COI primer specific yielded a band with the expected size of $500 \mathrm{bp}$ (Fig. 3). In the present study, the most appropriate ML model selected was Tamura 3- parameter model with the uniform rate among sites (T92). The phylogenetic tree for the mitochondrial COI composed of major genu-level clades, corresponding to the Chondrilla. This genus formed a clade with generally high bootstrap value in phylogenetic analysis $(\mathrm{ML}=100 \%$ and $\mathrm{NJ}=89 \%)$. Within the Chondrilla clade, the sequence 
was similar to a previously reported sequence of Chondrilla australiensis voucher MCZ from the United States of America (JX999064).

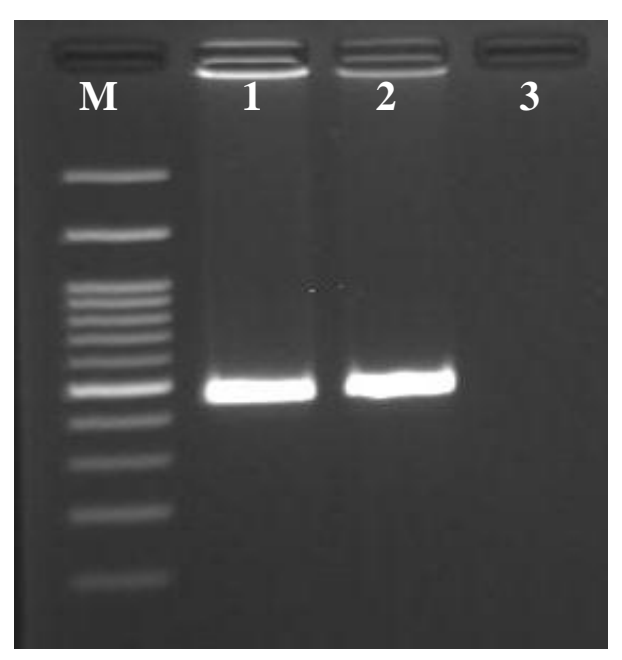

Fig. (3). PCR amplification of mit COI gene in the sponge sample. M: 100 bp DNA ladder, Lanes 1 and 2: amplified mit $C O I$ gene, Lanes 3: C- .

\subsection{Phylogenetic Analysis of Archaea}

In this study, PCR of total DNA isolated from Chondrilla australiensis samples using the universal archaeal primers showed a band of expected size of 1300 bp (Fig. 4).

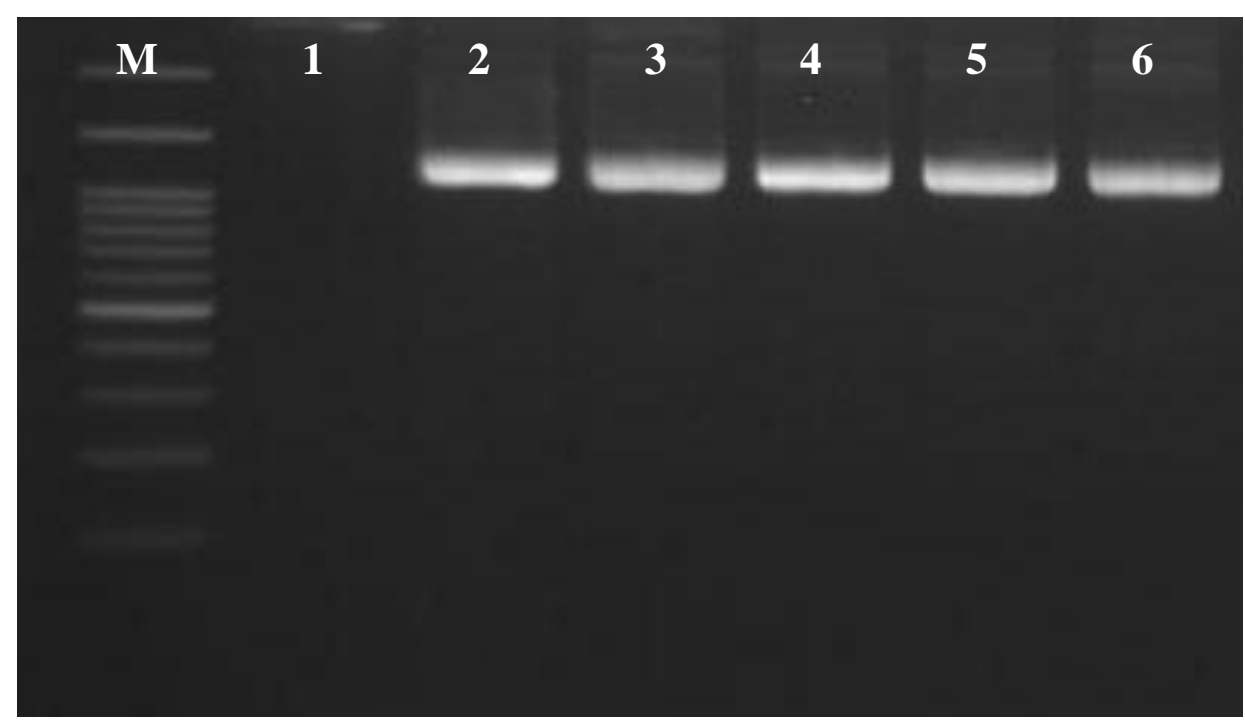

Fig. (4). PCR amplification of $16 S r R N A$ gene in the studied samples. M: 100 bp DNA ladder, Lane 1: C-, Lanes 2 to 6: amplified universal archaeal $16 S r R N A$ gene.

The PCR products were cloned into the pGEM $®$-T easy vector, producing 5 clone libraries with 20-50 white colonies each. 25 of these clones were run with M13 and universal primers. Of these, only 5 clones were amplified and subsequently sequenced. $16 \mathrm{~S} r R N A$ sequence analysis showed that these five "supposable" Archaeal clones are located in the uncultured archaeon group. Phylogenetic analysis of the $16 S$ rRNA sequence by ML and NJ analyses produced trees with nearly similar branching patterns. The best-fit ML model selected was Tamura-Nei with a gamma distribution of substitution rates among sites (TN93+G). Maximum likelihood and neighbour-joining analyses presented similarly well-resolved phylogenies.

In the present study, the phylogenetic tree for the $16 S r R N A$ gene composed of a major clade, corresponding to the 
uncultured group. Within this group, the PG_BU, Uncultured marine archaeon and Uncultured sponge symbiont formed a very well-supported clade in both ML $(100 \%)$ and $\mathrm{NJ}(99 \%)$ analyses (Fig. 5). Within this clade, the PG_BU and uncultured marine archaeon formed a clade supported by ML and NJ analyses ( $85 \%$ and $79 \%$, respectively).

Uncultured sponge symbiont formed a very well-supported monophyletic clade in all analyses (ML: 99\%, NJ: 99\%). Also well-supported class-level clades were recovered for Halobacteria (100\%, 97\%), Thermococci (100\%, 98\%), and Methanomicrobia $(100 \%, 99 \%)$. In this study, the $16 S$ rRNA gene sequence from Escherichia coli (J01859) was considered as outgroup.

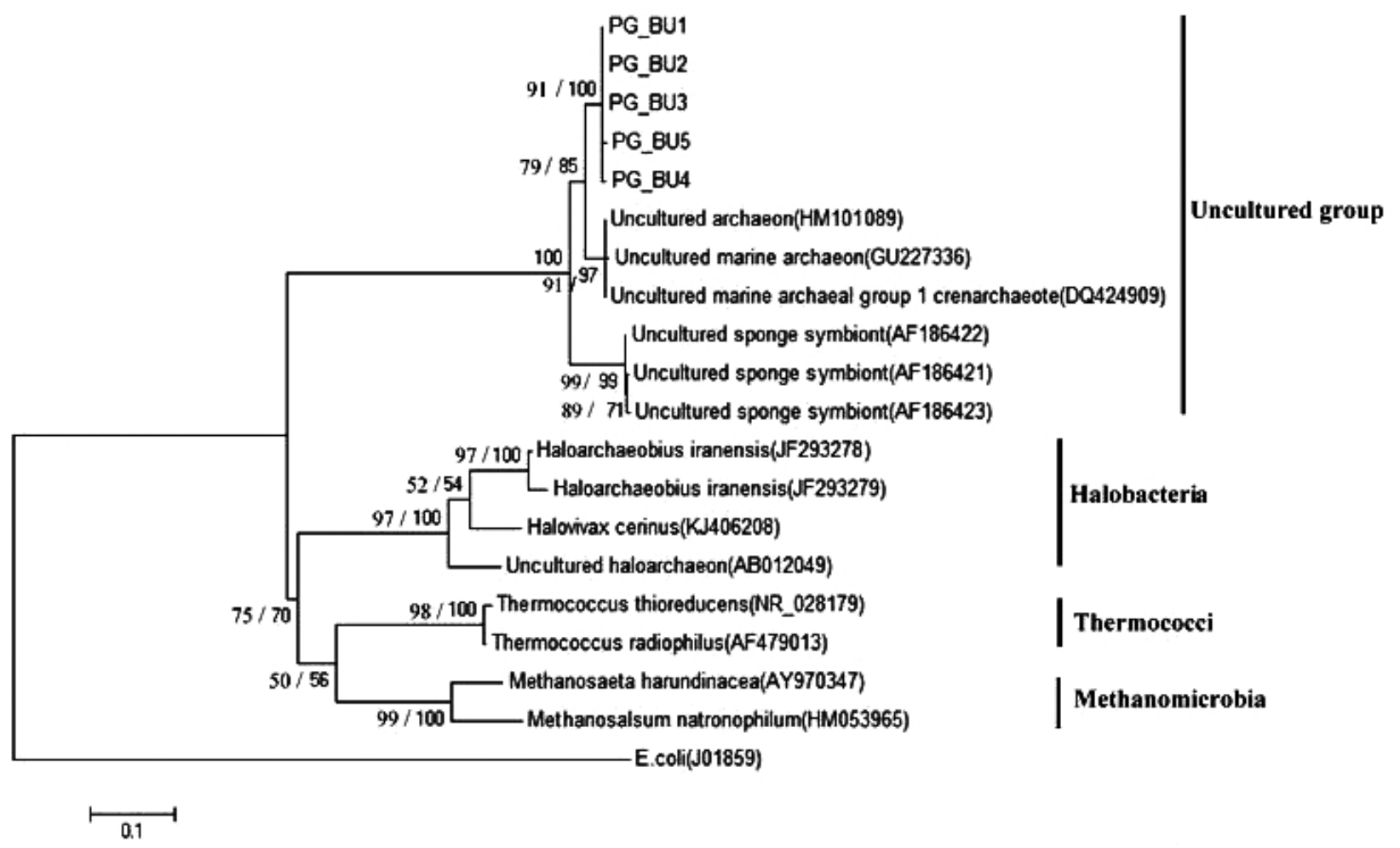

Fig. (5). Phylogenetic analysis of $16 S r R N A$ gene sequences from uncultured Archaea. The tree was constructed using the maximum likelihood method and bootstrap resampled 1000 times. Bootstrap values greater than $50 \%$ are indicated on the internal nodes. Scale bar: 0.1 substitutions per nucleotide position. Genbank accession numbers are noted after the name of the strains.

\subsection{Nucleotide Sequence Accession Numbers}

The mt COI gene sequence for the sponge sample was deposited in GenBank under accession number LC372995. While 16S rRNA gene sequences for the archaea were deposited under accession numbers LC216351 to LC216355.

\section{DISCUSSION}

To our knowledge, it is the first study focusing on the molecular taxonomy of sponge using multilocus DNA marker and also identification of symbiotic archaea through the culture-independent analysis of the $16 S r R N A$ gene in Iran.

The analysis of multilocus DNA marker along with the morphological features revealed that the sponge species belonged to Chondrilla australiensis isolate PG_BU4. This is the first report of the presence of the genus of Chondrilla in the Persian Gulf. Different studies have considered Chondrilla as one of the most distributed genera with about 17 species at different geographical locations [19, 25 - 29]. This genus is characterized based on the presence of siliceous spicules of the aster type alone, abounding with the cortex and surrounding the canals. This finding is in accordance with the morphological features of the studied sponge, here. Traditional taxonomy methods, when used along with DNA barcoding or other molecular techniques, may play an important role in the accurate taxonomy of sponges with very few phenotypical variations [29].

Archaeal communities are present in a wide range of sponges from different ecosystems under varying marine environmental conditions. Diversity, composition, functional ecology and distribution of symbiotic archaea in marine 
sponges have been investigated in different studies [5, 12, 30 - 34].

Based on these studies, the archaeal symbiont in marine sponges varied depending on host biogeography. In another word, the specific geographical location of sponges has a great influence on their specific archaeal signatures. In addition, structure and composition of sponge-associated archaeal communities can be changed in response to marine pollution [12]. The Persian Gulf as a semi-closed marine environment with specific physicochemical characteristics and high levels of oil pollution and petroleum wastes may have its unique sponge-associated archaeal composition.

The current work as the first investigation on the archaeal community of the Persian Gulf showed that Chondrilla australiensis harbors distinct uncultured archaea. In this study, the sequence from the Chondrilla australiensis PG_BU specimen formed a well-supported clade $(\mathrm{ML}=85 \%, \mathrm{NJ}=79 \%)$ with uncultured marine archaeon from USA [33], South China Sea [35], and also with uncultured sponge symbiont from Western Caroline Islands, Palau [36].

Since the previous decade, detection and molecular analysis of uncultured archaea $16 S r R N A$ gene sequences from environmental sources have greatly surpassed several orders of magnitude above those reported cultured counterparts [37]. It has been suggested that most of the environmental $16 \mathrm{~S} r R N A$ sequences of the high taxa will be introduced in the next several years [38]. Therefore, other biotypes and non-host environmental sources from the Persian Gulf have this potential to discover novel archaeal lineages using molecular analysis. Although currently, no laboratory-cultivated strains for the majority of sponge associate archaea are available, cultivation of uncultured archaea with high bioactive compounds and biotechnological potentials from sponge sources will be accessible in the near future. The cultivability of (previously uncultured) bacterial genera from three Mediterranean sponges was reported very recently [39].

Although the stability of the sponge-archaea associations could not be inferred in the current study, consistent association and host- specificity of symbiotic archaea in marine sponges have been reported in different studies [5, 31]. It has also been suggested that archaeal community composition and symbiont-sponge interactions have evolved in parallel from many millions of years ago [33]. As a limitation of the study, we did not assess the composition of archaea in non-sponge hosts or non-host environment including seawater column and sediment.

The accumulated knowledge from genes and genomes of uncultivated environmental archaea provided insights about the potential metabolic capabilities of some of these uncultivated archaea [40, 41]. Recently, the bioinformatics and functional insights into the lifestyle of symbiotic uncultured bacterial product factories in marine sponges were presented [42]. By using genomic, (meta) proteomic and chemical methods, it is possible to gain some metabolic insights into the uncultured archaea that we have found in the current study.

The members of sponge symbiotic microbial community may be involved in providing food and chemical defense molecules for sponges and protect them from ultraviolet light. Archaea play a major role in nitrogen metabolism of sponges and ammonia oxidation [5]. It is generally accepted that sponge-associated microbes including the archaeal members are the main producers of bioactive and biochemical metabolites that have been reported from marine sponges [32]. Hence, from a biotechnological viewpoint, the identification of sponge-associated archaea that may produce bioactive compounds with potential pharmaceutical applications is a very interesting research field [20].

\section{CONCLUSION}

The molecular identification of symbiotic archaea in a marine sponge collected from the Persian Gulf may promise a potential source for bioactive compounds with a range of activities including antibacterial properties against vectors of human diseases.

\section{ETHICS APPROVAL AND CONSENT TO PARTICIPATE}

Not applicable.

\section{HUMAN AND ANIMAL RIGHTS}

No Animals/Humans were used for studies that are base of this research.

\section{CONSENT FOR PUBLICATION}

Not applicable. 


\section{CONFLICT OF INTEREST}

The authors declare no conflict of interest, financial or otherwise.

\section{ACKNOWLEDGEMENTS}

This study was funded by the Persian Gulf Marine Biotechnology Research Center, Bushehr University of Medical Sciences (grant number 5457). Warm thanks are due to Dr. Zahra Amini and Dr. Yusheng M. Huang for their kind assistance.

\section{REFERENCES}

[1] Graça AP, Viana F, Bondoso J, et al. The antimicrobial activity of heterotrophic bacteria isolated from the marine sponge Erylus deficiens (Astrophorida, Geodiidae). Front Microbiol 2015; 6: 389. [http://dx.doi.org/10.3389/fmicb.2015.00389] [PMID: 25999928]

[2] Verhoeven JT, Kavanagh AN, Dufour SC. Microbiome analysis shows enrichment for specific bacteria in separate anatomical regions of the deep-sea carnivorous sponge Chondrocladia grandis. FEMS Microbiol Ecol 2017; 93(1): fiw214. [http://dx.doi.org/10.1093/femsec/fiw214] [PMID: 27756769]

[3] Giles EC, Kamke J, Moitinho-Silva L, et al. Bacterial community profiles in low microbial abundance sponges. FEMS Microbiol Ecol 2013; 83(1): 232-41.

[http://dx.doi.org/10.1111/j.1574-6941.2012.01467.x] [PMID: 22882238]

[4] Gao ZM, Wang Y, Lee OO, et al. Pyrosequencing reveals the microbial communities in the Red Sea sponge Carteriospongia foliascens and their impressive shifts in abnormal tissues. Microb Ecol 2014; 68(3): 621-32. [http://dx.doi.org/10.1007/s00248-014-0419-0] [PMID: 24760170]

[5] Zhang F, Pita L, Erwin PM, Abaid S, López-Legentil S, Hill RT. Symbiotic archaea in marine sponges show stability and host specificity in community structure and ammonia oxidation functionality. FEMS Microbiol Ecol 2014; 90(3): 699-707. [http://dx.doi.org/10.1111/1574-6941.12427] [PMID: 25227989]

[6] Regueiras A, Alex A, Pereira S, Costa MS, Antunes A, Vasconcelos V. Cyanobacterial diversity in the marine sponge Hymeniacidon perlevis from a temperate region (Portuguese coast, Northeast Atlantic). Aquat Microb Ecol 2017; 79: 259-72.

[http://dx.doi.org/10.3354/ame01830]

[7] Montalvo NF, Davis J, Vicente J, Pittiglio R, Ravel J, Hill RT. Integration of culture-based and molecular analysis of a complex spongeassociated bacterial community. PLoS One 2014; 9(3): e90517. [http://dx.doi.org/10.1371/journal.pone.0090517] [PMID: 24618773]

[8] Hooper JNA, van Soest RWM. Systema Porifera: A Guide to the Classification of Sponges. New York: Kluwer Academic/Plenum Publishing 2002; Vol. I.

[http://dx.doi.org/10.1007/978-1-4615-0747-5]

[9] Erwin PM, Thacker RW. Phylogenetic analyses of marine sponges within the order Verongida: A comparison of morphological and molecular data. Invertebr Biol 2007; 126: 220-34. [http://dx.doi.org/10.1111/j.1744-7410.2007.00092.x]

[10] Bayer K, Kamke J, Hentschel U. Quantification of bacterial and archaeal symbionts in high and low microbial abundance sponges using realtime PCR. FEMS Microbiol Ecol 2014; 89(3): 679-90. [http://dx.doi.org/10.1111/1574-6941.12369] [PMID: 24942664]

[11] Rodríguez-Marconi S, De la Iglesia R, Díez B, Fonseca CA, Hajdu E, Trefault N. Characterization of bacterial, archaeal and eukaryote symbionts from Antarctic sponges reveals a high diversity at a three-domain level and a particular signature for this ecosystem. PLoS One 2015; 10(9): e0138837.

[http://dx.doi.org/10.1371/journal.pone.0138837] [PMID: 26421612]

[12] Turque AS, Batista D, Silveira CB, et al. Environmental shaping of sponge associated archaeal communities. PLoS One 2010 ; 5(12): e15774. [http://dx.doi.org/10.1371/journal.pone.0015774] [PMID: 21209889]

[13] Alquéres SMC, Almeida RV, Clementino MM, Vieira RP, Almeida WI, Cardoso AM, et al. Exploring the biotechnologial applications in the archaeal domain. Braz J Microbiol 2007; 38: 398-405. [http://dx.doi.org/10.1590/S1517-83822007000300002]

[14] Alex A, Antunes A. Pyrosequencing characterization of the microbiota from Atlantic intertidal marine sponges reveals high microbial diversity and the lack of co-occurrence patterns. PLoS One $2015 ; 10(5)$ : e0127455. [http://dx.doi.org/10.1371/journal.pone.0127455] [PMID: 25992625]

[15] Reitschuler C, Hofmann K, Illmer P. Abundances, diversity and seasonality of (non-extremophilic) Archaea in Alpine freshwaters. Antonie van Leeuwenhoek 2016; 109(6): 855-68. [http://dx.doi.org/10.1007/s10482-016-0685-6] [PMID: 27002962]

[16] Moitinho-Silva L, Bayer K, Cannistraci CV, et al. Specificity and transcriptional activity of microbiota associated with low and high microbial abundance sponges from the Red Sea. Mol Ecol 2014; 23(6): 1348-63. [http://dx.doi.org/10.1111/mec.12365] [PMID: 23957633] 
[17] Najafi A. Book review: Medicinal sponges of the Persian Gulf. Iran South Med J 2012; 15: 81-3.

[18] Jackson SA, Kennedy J, Morrissey JP, O’Gara F, Dobson AD. Pyrosequencing reveals diverse and distinct sponge-specific microbial communities in sponges from a single geographical location in Irish waters. Microb Ecol 2012; 64(1): $105-16$. [http://dx.doi.org/10.1007/s00248-011-0002-x] [PMID: 22281804]

[19] van Soest R. Chondrilla nucula Schmidt, 1862. In: van Soest RWM, Boury-Esnault N, Hooper JNA, Rützler K, de Voogd NJ, de Glasby BA, Hajdu E, Pisera AB, Manconi R, Schoenberg C, Janussen D, Tabachnick KR, Klautau M, Picton B, Kelly M, Vacelet J, Dohrmann M, Díaz MC, Cárdenas P, editors. World Porifera database at http:/www.marinespecies.org/porifera/porifera.php?p=taxdetails\&id=132021 2015

[20] Schmitt S, Tsai P, Bell J, et al. Assessing the complex sponge microbiota: Core, variable and species-specific bacterial communities in marine sponges. ISME J 2012; 6(3): 564-76. [http://dx.doi.org/10.1038/ismej.2011.116] [PMID: 21993395]

[21] Becking LE, Erpenbeck D, Peijnenburg KT, de Voogd NJ. Phylogeography of the sponge Suberites diversicolor in Indonesia: insights into the evolution of marine lake populations. PLoS One 2013; 8(10): e75996. [http://dx.doi.org/10.1371/journal.pone.0075996] [PMID: 24098416]

[22] Kim DW, Yoo WG, Park HC, et al. DNA barcoding of fish, insects, and shellfish in Korea. Genomics Inform 2012; 10(3): 206-11. [http://dx.doi.org/10.5808/GI.2012.10.3.206] [PMID: 23166532]

[23] Amoozegar MA, Makhdoumi-Kakhki A, Mehrshad M, et al. Halovivax cerinus sp. nov., An extremely halophilic archaeon from a hypersaline lake. Int J Syst Evol Microbiol 2015; 65(Pt 1): 65-70.

[http://dx.doi.org/10.1099/ijs.0.069757-0] [PMID: 25269847]

[24] Erwin PM, Olson JB, Thacker RW. Phylogenetic diversity, host-specificity and community profiling of sponge-associated bacteria in the northern Gulf of Mexico. PLoS One 2011; 6(11): e26806.

[http://dx.doi.org/10.1371/journal.pone.0026806] [PMID: 22073197]

[25] Usher KM, Sutton DC, Toze S, Kuo J, Fromont J. Biogeography and phylogeny of Chondrilla species (Demospongiae) in Australia. Mar Ecol Prog Ser 2004; 270: 117-27. [http://dx.doi.org/10.3354/meps270117]

[26] Cavalcanti FF, Zilberberg C, Klautau M. Seasonal variation of morphological characters of Chondrilla aff. nucula (Porifera: Demospongiae) from the south-east coast of Brazil. J Mar Biol Assoc U K 2007; 87: 1727-32. [http://dx.doi.org/10.1017/S0025315407059887]

[27] Rützler K, Duran S, Piantoni C. Adaptation of reef and mangrove sponges to stress: Evidence for ecological speciation exemplified by Chondrilla caribensis new species (Demospongiae, Chondrosida). Mar Ecol (Berl) 2007; 28: 95-111. [http://dx.doi.org/10.1111/j.1439-0485.2007.00183.x]

[28] Fromont J, Usher KL, Sutton DC, Toze S, Kuo J. Species of the sponge genus Chondrilla (Demospongiae: Chondrosida: Chondrillidae) in Australia. Rec West Aust Mus 2008; 24: 469-86. [http://dx.doi.org/10.18195/issn.0312-3162.24(4).2008.469-486]

[29] Immanuel T, Krishnan P, Raghuraman R, Veerappan N, Dam-Roy S. New records of Chondrilla australiensis and Chondrilla grandistellata (demospongiae: Chondrosida: Chondrillidae) from Havelock Island, South Andaman, India. J Threat Taxa 2015; 7: 8167-72. [http://dx.doi.org/10.11609/jott.2432.7.14.8167-8172]

[30] Webster NS, Watts JE, Hill RT. Detection and phylogenetic analysis of novel crenarchaeote and euryarchaeote 16S ribosomal RNA gene sequences from a Great Barrier Reef sponge. Mar Biotechnol (NY) 2001; 3(6): 600-8. [http://dx.doi.org/10.1007/s10126-001-0065-7] [PMID: 14961332]

[31] Margot H, Acebal C, Toril E, Amils JR, Puentes F. Consistent association of crenarchaeal Archaea with sponges of the genus Axinella. Mar Biol 2002; 140: 739-45. [http://dx.doi.org/10.1007/s00227-001-0740-2]

[32] Lee EY, Lee HK, Lee YK, Sim CJ, Lee JH. Diversity of symbiotic archaeal communities in marine sponges from Korea. Biomol Eng 2003; 20(4-6): 299-304. [http://dx.doi.org/10.1016/S1389-0344(03)00034-0] [PMID: 12919812]

[33] Holmes BM, Blanch H. Genus-specific associations of marine sponges with group I crenarchaeotes. Mar Biol 2007; 150: 759-72. [http://dx.doi.org/10.1007/s00227-006-0361-x]

[34] Polónia AR, Cleary DF, Freitas R, de Voogd NJ, Gomes NC. The putative functional ecology and distribution of archaeal communities in sponges, sediment and seawater in a coral reef environment. Mol Ecol 2015; 24(2): 409-23. [http://dx.doi.org/10.1111/mec.13024] [PMID: 25438824]

[35] Liu F, Han M, Zhang F, Zhang B, Li Z. Distribution and abundance of archaea in south China sea sponge Holoxea sp. and the presence of ammonia-oxidizing archaea in sponge cells. Evid Based Complement Alternat Med 2011; 2011: 723696. [http://dx.doi.org/10.1155/2011/723696] [PMID: 21869898]

[36] Hentschel U, Hopke J, Horn M, et al. Molecular evidence for a uniform microbial community in sponges from different oceans. Appl Environ Microbiol 2002; 68(9): 4431-40.

[http://dx.doi.org/10.1128/AEM.68.9.4431-4440.2002] [PMID: 12200297] 
[37] Auguet JC, Barberan A, Casamayor EO. Global ecological patterns in uncultured Archaea. ISME J 2010; 4(2): 182-90. [http://dx.doi.org/10.1038/ismej.2009.109] [PMID: 19847207]

[38] Yarza P, Yilmaz P, Pruesse E, et al. Uniting the classification of cultured and uncultured bacteria and archaea using 16S rRNA gene sequences. Nat Rev Microbiol 2014; 12(9): 635-45.

[http://dx.doi.org/10.1038/nrmicro3330] [PMID: 25118885]

[39] Versluis D, McPherson K, van Passel MWJ, Smidt H, Sipkema D. Recovery of previously uncultured bacterial genera from three Mediterranean sponges. Mar Biotechnol (NY) 2017; 19(5): 454-68. [http://dx.doi.org/10.1007/s10126-017-9766-4] [PMID: 28695385]

[40] Schleper C, Jurgens G, Jonuscheit M. Genomic studies of uncultivated archaea. Nat Rev Microbiol 2005; 3(6): 479-88. [http://dx.doi.org/10.1038/nrmicro1159] [PMID: 15931166]

[41] Lazar CS, Baker BJ, Seitz KW, Teske AP. Genomic reconstruction of multiple lineages of uncultured benthic archaea suggests distinct biogeochemical roles and ecological niches. ISME J 2017; 11(5): 1118-29. [http://dx.doi.org/10.1038/ismej.2016.189] [PMID: 28085154]

[42] Lackner G, Peters EE, Helfrich EJ, Piel J. Insights into the lifestyle of uncultured bacterial natural product factories associated with marine sponges. Proc Natl Acad Sci USA 2017; 114(3): E347-56. [http://dx.doi.org/10.1073/pnas.1616234114] [PMID: 28049838]

(C) 2018 Najafi et al.

This is an open access article distributed under the terms of the Creative Commons Attribution 4.0 International Public License (CC-BY 4.0), a copy of which is available at: (https://creativecommons.org/licenses/by/4.0/legalcode). This license permits unrestricted use, distribution, and reproduction in any medium, provided the original author and source are credited. 